\title{
KORELASI STRATEGI PEMBELAJARAN KONSTRUKTIVISTIK PADA MATA PELAJARAN PENDIDIKAN KEWARGANEGARAAN DENGAN INTERAKSI BELAJAR DI KELAS XI MADRASAH ALIYAH SWASTA DARUL ULUM PONTIANAK
}

\author{
Moad $^{1}$, Yeni Ristianti ${ }^{2}$ \\ Program Studi PPKN Fakultas Ilmu Pendidikan dan Pengetahuan Sosial IKIP PGRI Pontianak \\ Jl. Ampera Nomor 88 Pontianak-78116, Telepon (0561) 748219 Fax. (0561) 6589855 \\ Email: moad_54@yahoo.com
}

\begin{abstract}
Abstrak
Tujuan penelitian ini adalah untuk mengetahui dan mendapatkan informasi yang jelas dan akurat mengenai korelasi pembelajaran konstruktivistik pada mata pelajaran Pendidikan Kewarganegaraan dengan interaksi belajar di kelas XI Madrasah Aliyah Swasta Darul Ulum Pontianak. Metode yang digunakan adalah metode deskriptif dengan bentuk penelitian studi hubungan. Teknik pengumpulan data yang digunakan adalah teknik komunikasi tidak langsung dengan alat pengumpul data angket dan teknik studi dokumenter dengan alat pengumpulan data dokumen-dokumen. Populasi dalam penelitian ini adalah siswa kelas XI MAS Darul Ulum Pontianak yang berjumlah 75 orang dan seluruh anggota populasi menjadi sampel penelitian. Teknik analisis data menggunakan rumus perhitungan persentase dan rumus perhitungan koefisien korelasi product moment.
\end{abstract}

Kata Kunci : Strategi Pembelajaran Konstruktivistik, Interaksi Belajar.

\begin{abstract}
The purpose of this study was to find out and get clear and accurate information about the correlation of constructive learning in Citizenship Education subjects with learning interactions in class XI of Darul Ulum Private Islamic School in Pontianak. The method used is descriptive method with the form of relationship study research. Data collection techniques used are indirect communication techniques with questionnaire data collection tools and documentary study techniques with data collection tools documents. The population in this study were class XI students of MAS Darul Ulum Pontianak, amounting to 75 people and all members of the population became the study sample. The data analysis technique uses the percentage calculation formula and the product moment correlation coefficient calculation formula.
\end{abstract}

Keywords: Constructivistic Learning Strategy, Learning Interaction.

\section{PENDAHULUAN}

Guru yang mampu melaksanakan tanggung jawabnya terhadap proses pembelajaran, khususnya yang berkenaan dengan penciptaan suasana belajar yang menyenangkan serta sesuai dengan tingkat kemampuan siswa, berarti telah berupaya membantu siswa untuk melaksanakan kegiatan belajar dengan optimal. Salah satu upaya yang dilakukan oleh guru berkenaan dengan tanggung jawabnya untuk menciptakan proses pembelajaran yang menyenangkan adalah merancang sistem pembelajaran yang mampu menarik minat dan keaktifan siswa untuk melakukan kegiatan belajar.

Berkenaan dengan sistem pembelajaran, Wina Sanjaya (2008:195) mengemukakan bahwa: "Sistem pembelajaran adalah satu kesatuan komponen dalam pembelajaran yang satu sama lain saling berkaitan untuk mencapai hasil pembelajaran yang optimal sesuai dengan tujuan yang telah ditetapkan”. Sedangkan menurut, Oscar A. Oeser (1996:15): “Study system represent an bow outlines 
in activity of study to reach target which have been marked with lines". Sistem pembelajaran merupakan suatu garis-garis besar haluan dalam kegiatan pembelajaran untuk mencapai tujuan yang telah digariskan.

Salah satu sistem yang dapat digunakan guru dalam proses pembelajaran di kelas adalah pembelajaran konstruktivistik. Menurut Udin S. Winataputra (2007:6.6) pembelajaran konstruktivistik adalah: "Proses belajar yang lebih menekankan pada proses dari pada hasil". Sedangkan menurut Saekhan Muchith (2008:71) cara pandang teori konstruktivisme adalah: "Belajar merupakan proses untuk membangun pengetahuan melalui pengalaman nyata di lapangan. Artinya siswa akan cepat memiliki pengetahuan, jika pengetahuan itu dibangun atas dasar realitas yang ada di dalam masyarakat".

Berdasarkan kedua pendapat di atas, maka dapat disimpulkan bahwa pembelajaran konstruktivistik adalah proses pembelajaran yang lebih mengutamakan proses belajar dari pada hasil yang dicapai, sehingga dalam pelaksanaannya, siswa tidak hanya menerima pengetahuan dari guru, tetapi berupaya untuk membangun sendiri pengetahuan yang ada dengan cara menemukan ide-ide yang ada dan kemudian menerapkannya.

Melalui pembelajaran konstruktivistik, siswa mencoba untuk mencari tahu dengan menggunakan berbagai sumber belajar untuk menjelaskan terjadinya sesuatu. Sebagaimana yang dikemukakan oleh Udin S. Winataputra (2007:6.25) yaitu: "Pembelajaran konstruktivistik menekankan pada aktivitas siswa untuk menemukan sesuatu guna membangun pengetahuannya, sehingga dalam prosesnya mungkin akan terjadi kegagalan, namun kegagalan ini merupakan salah satu bagian dari proses belajar". Pendapat ini ,menandakan bahwa dengan pembelajaran konstruktivistik, siswa akan terbiasa melakukan interaksi dengan sumber belajar maupun guru atau dengan siswa lainnya untuk menemukan konsep. Hasil dari komunikasi tersebut tersebut berguna untuk melatih mental siswa untuk terus menerus menggali informasi mengenai materi pelajaran dan terus memotivasi diri untuk mencapai suatu keberhasilan.

Komunikasi dalam proses pembelajaran sebagaimana yang dikemukakan di atas, dalam dunia pendidikan dikenal dengan istilah interaksi belajar. Interaksi belajar dalam proses pembelajaran sendiri diartikan sebagai proses komunikasi yang terjadi dalam proses pembelajaran. Idri Shafaat (2009:61) mengemukakan bahwa: "Interaksi belajar dalam proses pembelajaran adalah komunikasi timbal balik antara pengajar dan yang diajar dengan maksud untuk mencapai tujuan pembelajaran". Dalam interaksi belajar, pengajar sebagai komunikator menyampaikan dan membahas bersama siswa pesan berupa ilmu pengetahuan dalam situasi yang telah diciptakan secara sengaja.

Suatu interaksi belajar dalam pembelajaran secara sadar dilakukan untuk mencapai tujuan. Dalam hal ini Mares Colin (1996:63) mengemukakan bahwa: "Put accross interaction will become 
tired bridge of target of expected study". Artinya, interaksi yang dilakukan dengan baik akan menjadi jembatan tercapainya tujuan pembelajaran yang diharapkan. Hal ini menunjukkan bahwa tercapainya tujuan tergantung pada bagaimana interaksi yang dilaksanakan.

Interaksi edukatif dapat berjalan dengan optimal, jika ditunjang penggunaan pembelajaran yang tepat. Hal ini berdasarkan pada pendapat Idri Shafaat (2009:63) yaitu: "Dalam interaksi guru mengarahkan siswa pada tujuan pembelajaran dengan teknik, metode dan prosedur yang berlaku". Artinya, pelaksanaan interaksi belajar dilakukan untuk mencapai tujuan pembelajaran dengan menggunakan cara-cara belajar mengajar yang diterapkan.

Berdasarkan pendapat yang dikemukakan di atas, maka dapat dikatakan pembelajaran konstruktivistik dapat menjadi salah satu alternatif pembelajaran yang dapat digunakan untuk mengefektifkan interaksi belajar yang dilakukan dalam proses pembelajaran, termasuk dalam proses pembelajaran Pendidikan Kewarganegaraan. Artinya, dengan pembelajaran konstruktivistik, maka diharapkan kemampuan siswa untuk melakukan interaksi belajar semakin meningkat, sebab pembelajaran konstruktivistik memberikan ruang kepada siswa untuk dapat berkomunikasi dan berinteraksi guna memperoleh informasi mengenai materi pelajaran.

Model konstruktivistik dalam pembelajaran adalah suatu proses pembelajaran dimana siswa aktif secara mental dalam membangun pengetahuannya, yang dilandasi oleh struktur kognitif yang telah dimilikinya. Adapun guru dalam penggunaan model ini berperan sebagai fasilitator dan mediator pembelajaran. Pembelajaran lebih berfokus terhadap suksesnya siswa dalam mengorganisasikan pengalaman mereka. Dengan diterapkannya pembelajaran konstruktivisme dalam pembelajaran PKn, siswa diharapkan dapat lebih aktif dalam pembelajaran dan lebih memahami penjelasan guru sehingga tujuan pembelajaran dapat tercapai dengan baik. Dengan ini juga diharapkan membangun pendidikan yang demokratis.

Melalui proses pra observasi yang peneliti lakukan di kelas XI Madrasah Aliyah Swasta Darul Ulum Pontianak, penulis melihat bahwa pembelajaran konstruktivistik telah diterapkan oleh guru Pendidikan Kewarganegaraan. Hal ini dapat dilihat dari proses pembelajaran, dimana siswa diberi kesempatan oleh guru untuk menggali informasi materi pelajaran semaksimal mungkin, melalui proses interaksi dan komunikasi, baik antar sesama siswa, dengan guru maupun dengan sumber belajar.

Di sisi lain, penulis melihat beberapa siswa aktif dalam berinteraksi dengan guru dalam proses pembelajaran, seperti bertanya, menjawab dan menanggapi. Namun, masih terlihat siswa-siswa yang kurang mampu berinteraksi dengan baik, acuh tak acuh terhadap proses pembelajaran dan perlu mendapat ketegasan dari guru Pendidikan Kewarganegaraan agar dapat mendukung terciptanya suasana belajar yang diharapkan. Kenyataan ini menjadikan penulis tertarik untuk melakukan 
penelitian tentang Korelasi Pembelajaran Konstruktivistik pada mata pelajaran Pendidikan Kewarganegaraan dengan Interaksi Belajar di Kelas XI Madrasah Aliyah Swasta Darul Ulum Pontianak.

\section{METODE}

Setiap penelitian memerlukan metode untuk mencapai suatu tujuan, sebaliknya tanpa adanya metode yang jelas, penelitian itu sendiri tidak akan dapat berjalan sebagaimana yang diharapkan, karena itu metode dalam suatu penelitian sangat diperlukan. Hal ini sesuai dengan pendapat Emzir (2009:26) yang mengemukakan bahwa: "Metode penelitian adalah suatu pendekatan atau cara yang dilakukan untuk memperoleh data dalam suatu penelitian.

Selanjutnya dalam suatu penelitian meliputi bermacam-macam, hal ini sejalan dengan pendapat Zuldafrial (2010:23) yang menyatakan bahwa: "Ada tiga metode penelitian dengan pendekatan kuantitatif, yaitu metode survey, metode deskriptif dan metode eksperimen". Dari uraian tersebut, maka dapat ditetapkan dalam penelitian ini metode yang dipilih adalah metode deskriptif. Sehubungan dengan hal tersebut, Zuldafrial (2010:23) menyatakan bahwa: "Metode deskriptif adalah suatu strategi pemecahan masalah penelitian dengan menggunakan angket sebagai alat pengumpul data utamanya". Dipilihnya metode deskriptif ini karena dalam proses pengumpulan data, peneliti akan menggunakan angket sebagai alat pengumpul data utama.

Bentuk penelitian dalam penelitian ini adalah bentuk studi hubungan. Hal ini disebabkan karena penelitian ini bermaksud mendeskripsikan hubungan atau pengaruh variabel bebas atau variabel $\mathrm{X}$ yaitu, pembelajaran konstruktivistik pada mata pelajaran Pendidikan Kewarganegaraan dengan variabel terikat atau variabel Y yaitu, interaksi belajar.

Selanjutnya yang menjadi populasi dalam penelitian ini adalah guru Pendidikan Kewarganegaraan dan siswa kelas XI Madrasah Aliyah Swasta Darul Ulum Pontianak. Karena jumlah populasi yang tidak begitu besar, yaitu 75 orang siswa, maka peneliti mengambil keseluruhan jumlah populasi untuk dijadikan sampel penelitian. Dengan demikian, penelitian ini termasuk dalam penelitian populasi, dengan jumlah sampel 75 orang siswa dan ditambah 1 orang guru Pendidikan Kewarganegaraan.

Suatu penelitian memerlukan teknik tertentu untuk memperlancar proses penelitian dan teknik tersebut harus sesuai dengan pencapaian tujuan penelitian. Penetapan teknik yang tepat dalam penelitian akan berdampak positif dan memiliki arti penting yang sangat strategis, sebab semua yang akan didata, dianalisis dan diinterpretasikan akan menjadi tepat. Dalam penelitian ini menggunakan teknik komunikasi tidak langsung sebagai teknik utama dan teknik studi dokumenter sebagai objek pendukung dalam pengumpul data. 
Berdasarkan teknik pengumpulan data yang digunakan, maka alat pengumpul data yang sesuai dengan teknik-teknik tersebut adalah angket dan dokumen. Teknik analisis data yang digunakan dalam penelitian ini adalah dengan menggunakan rumus perhitungan persentase dan rumus perhitungan koefisien korelasi product moment.

\section{HASIL DAN PEMBAHASAN}

Langkah sebelum penelitian dilakukan, terlebih dahulu peneliti memperbaiki desain penelitian untuk diteruskan menjadi skripsi dan menyusun laporan hasil seminar. Hasil dari seminar desain penelitian, menjadi rujukan peneliti untuk melakukan perbaikan desain penelitian untuk kemudian dijadikan skripsi. Saran dari dosen dan mahasiswa penyanggah pada saat seminar memberikan masukan berarti bagi peneliti, sehingga dianggap perlu dilakukan perbaikan terhadap desain penelitian dan penyusunan laporan hasil seminar. Untuk selanjutnya, setelah perbaikan desain penelitian dan laporan hasil seminar selesai disusun dan disetujui oleh pembimbing maka peneliti bersiap melakukan penelitian. Setelah memperbaiki desain penelitian dan menyusun laporan hasil seminar, peneliti menyusun instrumen penelitian berupa angket.

Penyusunan angket didahului dengan penyusunan kisi-kisi berdasarkan variabel dan aspek variabel yang akan diteliti. Berdasarkan kisi-kisi yang telah disusun, maka disusunlah angket untuk variable bebas dan terikat yang masing-masing berjumlah enam belas (16) item dan memiliki empat (4) pilihan jawaban. Setelah instrumen penelitian disusun, harus dikonsultasikan terlebih dahulu kepada kedua Dosen Pembimbing. Jika sudah disetujui, maka alat atau instrumen penelitian tersebut baru dapat dipergunakan dalam penelitian.

Data yang telah terkumpul kemudian peneliti periksa satu persatu, guna mengetahui ada tidaknya kekeliruan dalam pengisian angket penelitian. Dari hasil pemeriksaan, angket yang terkumpul kembali dalam keadaan utuh dengan jumlah yang sesuai. Pengisian angket telah dilakukan dengan benar, sehingga hasil jawaban angket dapat diolah sebagaimana mestinya.

Berdasarkan analisis persentase di atas, maka dapat diinterpretasikan bahwa pembelajaran konstruktivistik pada mata pelajaran Pendidikan Kewarganegaraan di kelas XI Madrasah Aliyah Swasta Darul Ulum Pontianak dikategorikan baik, dengan pencapaian frekuensi (f) sebagai skor aktual adalah sebesar 3783 dan jumlah frekuensi (N) sebagai skor maksimal ideal adalah sebesar 4800, sehingga persentase yang dicapai adalah 78,81\% dan masuk dalam rentang persentase $70 \%$ 79\% dengan kategori "Baik".

Berdasarkan analisis persentase di atas, maka dapat diinterpretasikan bahwa interaksi belajar di kelas XI Madrasah Aliyah Swasta Darul Ulum Pontianak dikategorikan baik, dengan pencapaian frekuensi (f) yang diperoleh sebagai skor aktual adalah 3719 dan jumlah frekuensi (N) sebagai skor 
maksimal ideal adalah sebesar 4800, sehingga persentase yang dicapai adalah 77,48\% dan masuk dalam rentang persentase 70\%-79\% dengan kategori "Baik".

Diketahui nilai $\mathrm{r}_{\mathrm{xy}}$ hitung adalah 0,522 , sedangkan nilai $\mathrm{r}_{\mathrm{xy}}$ tabel untuk taraf signifikan $5 \%$ dengan $\mathrm{N}=75$ sebagaimana yang dijabarkan pada lampiran adalah 0,522. Dengan demikian, nilai $\mathbf{r}_{\mathrm{xy}}$ hitung lebih besar dari nilai $r_{x y}$ tabel atau nilai $r_{x y}$ hitung $>$ nilai $r_{x y}$ tabel $(0,522>0,227)$ atau dengan kata lain nilai korelasi yang didapat dinyatakan signifikan. Berdasarkan hasil perhitungan korelasi atau $r_{x y}$ hitung yaitu sebesar 0,522. Maka, nilai $r_{x y}$ hitung lebih besar dari nilai $r_{x y}$ tabel atau nilai $r_{x y}$ hitung > nilai $r_{x y}$ tabel $(0,522>0,227)$, sehingga hipotesis alternatif (Ha) diterima dan Hipotesis nol (Ho) ditolak. Artinya, hipotesis yang diterima adalah "Terdapat korelasi pembelajaran konstruktivistik pada mata pelajaran Pendidikan Kewarganegaraan dengan interaksi belajar di kelas XI Madrasah Aliyah Swasta Darul Ulum Pontianak".

Nilai korelasi yang didapat berdasarkan hasil penelitian adalah 0,522 dan dinyatakan signifikan. Nilai sebesar 0,522 ini masuk dalam rentang nilai 0,40-0,70 dengan interpretasi “Antara variabel X dan variabel Y terdapat korelasi yang sedang atau cukup". Ini berarti, dapat disimpulkan bahwa korelasi pembelajaran konstruktivistik pada mata pelajaran Pendidikan Kewarganegaraan dengan interaksi belajar di kelas XI Madrasah Aliyah Swasta Darul Ulum Pontianak tergolong sedang atau cukup dengan nilai korelasi 0,522. Hal ini membuktikan bahwa variabel X merupakan salah satu faktor yang memiliki hubungan dengan variabel Y. Artinya, korelasi pembelajaran konstruktivistik pada mata pelajaran Pendidikan Kewarganegaraan dengan interaksi belajar di kelas XI Madrasah Aliyah Swasta Darul Ulum Pontianak tergolong cukup signifikan.

\section{SIMPULAN}

Berdasarkan hasil pengolahan dan analisis data, maka secara umum dapat disimpulkan bahwa korelasi strategi pembelajaran konstruktivistik pada mata pelajaran Pendidikan Kewarganegaraan dengan interaksi belajar di kelas XI Madrasah Aliyah Swasta Darul Ulum Pontianak tergolong sedang atau cukup dengan nilai korelasi 0,522. Artinya, korelasi pembelajaran konstruktivistik pada mata pelajaran Pendidikan Kewarganegaraan dengan interaksi belajar di kelas XI Madrasah Aliyah Swasta Darul Ulum Pontianak tergolong cukup signifikan.

Sebagai rumusan penelitian agar sejalan dengan rumusan sub-sub masalah penelitian yang telah ditentukan, adapun hasil dari rumusan sub-sub masalah penelitian tersebut dapat disimpulkan sebagai berikut:

1. Strategi pembelajaran konstruktivistik pada mata pelajaran Pendidikan Kewarganegaraan di kelas XI Madrasah Aliyah Swasta Darul Ulum Pontianak dikategorikan baik dengan persentase yang dicapai adalah 78,81\%, karena aspek-aspek dari strategi pembelajaran konstruktivistik telah 
dilaksanakan dengan baik. Hasil ini didasarkan pada temuan hasil penelitian yang berkenaan dengan pembelajaran konstruktivistik yang menunjukkan hasil baik.

2. Interaksi belajar di kelas XI Madrasah Aliyah Swasta Darul Ulum Pontianak dikategorikan baik dengan persentase yang dicapai adalah 77,48\%, karena aspek-aspek dari interaksi belajar telah dilaksanakan dengan baik. Hasil ini didasarkan pada temuan hasil penelitian yang berhubungan dengan interaksi belajar yang menunjukkan hasil baik.

3. Terdapat korelasi pembelajaran konstruktivistik pada mata pelajaran Pendidikan Kewarganegaraan dengan interaksi belajar di kelas XI Madrasah Aliyah Swasta Darul Ulum Pontianak yang cukup signifikan, dengan nilai korelasi 0,522 .

\section{DAFTAR PUSTAKA}

Anggoro, Toha, M dan Andriani Durri (2007). Metode Penelitian. Jakarta: Universitas Terbuka. Djamarah, Bahri, Syaiful dan Zain, Aswan (2006). Strategi Belajar Mengajar. Jakarta: Rineka Cipta. Emzir (2009). Metode Penelitian Pendidikan: Kuantitatif dan Kualitatif. Jakarta: Rajawali Press. Jonassen (1991). Educational Psychology: Theory and Practice. Massachusetts: Allyn and Bacon.

Nawawi, Hadari (2003), Metode Penelitian Bidang Sosial, Yogyakarta: Gajah Mada University Press.

Nur, M (2002). Teori Pembelajaran Sosial dan Teori Pembelajaran Perilaku. Surabaya: IKIP Surabaya.

Oeser, O, Oscar (1996). Learning and Human Abilities, Educational Psychology: Fourth Edition. New York: Harper \& New Publishers.

Prasetyo, Bambang dan Jannah, Miftahul, Lina (2010). Metode Penelitian Kuantitatif. Jakarta: Rajawali Press.

Ridwan dan Akdon (2009). Rumus dan Data dalam Analisis Statistika. Bandung: Alfabeta.

Roestiyah, N.K (2008). Strategi Belajar Mengajar. Jakarta: Rineka Cipta.

Rohani, Ahmad dan Ahmadi, Abu (1992). Pengelolaan Pengajaran. Jakarta: Rineka Cipta. (2001). Teknik Belajar yang Tepat. Bandung : PT. Remadja Rosdakarya.

Sardiman, A.M (2006). Interaksi dan Motivasi Belajar Mengajar. Jakarta: Raja Grafindo Persada.

Shafaat, Idri (2009). Optimized Learning Strategy. Jakarta: Prestasi Pustaka Publisher.

Suardi, Edi (2000). Paedagogik. Bandung: Remaja Rosdakarya.

Subana, M dan Sudrajat (2002). Dasar-dasar Penelitian Ilmiah. Jakarta: Pustaka Setia.

Sudijono, Anas (2009). Statistik untuk Penelitian. Jakarta: Rajawali Press.

Sudjana, Nana (2009). Penilaian Hasil Proses Belajar Mengajar. Bandung: Remaja Rosdakarya.

Surachmad, Winarno (2000), Pengantar Penelitian Ilmiah Dasar: Metode dan Teknik, Bandung: Tarsito. 
Tim Penyusun (2015). Pedoman Akademik dan Kemahasiswaan: Pedoman Penulisan Skripsi dan Makalah. Pontianak: IKIP PGRI Pontianak.

Trianto (2007). Model-model Pembelajaran Berorientasi Konstruktivistik. Jakarta: Prestasi Pustaka Publisher.

Winataputra, S. Udin (2007). Teori Belajar dan Pembelajaran. Jakarta: Universitas Terbuka.

Wirartha, I Made (2006). Pedoman Penulisan Usulan Penelitian, Skripsi dan Tesis. Yogyakarta: Andi.

Zuldafrial (2010). Penelitian Kuantitatif. Pontianak: STAIN Pontianak Press. 